\title{
Presidential Abuse of Foreign Trips and Crisis of Governance in Nigeria: A Reflection on Muhamadu Buhari's Regime, 2015-2019
}

\author{
Celestine Uchechukwu Udeogu, Okorie Albert, Ph.D*, Chikwado Ezugworie \\ Department of Political Science, University of Nigeria, Nsukka
}

*Corresponding Author: Okorie Albert, Ph.D, Department of Political Science, University of Nigeria, Nsukka

\begin{abstract}
Developing trends among African leaders is the penchant and crave for foreign trips under the guise of official assignment or to receive medical attention. This article relies on the Absense of the Father Theory and argued that President Mohamadu Buhari's abuse of foreign trips did not only create crisis of governance but also threatened his regime and the stability of the Nation. The article further argued that the Presidential abuse of foreign trips violated Sections 145 and 46 of the 1999 Constitution and National Health Act respectively. Documentary method and content analysis were employed for data collection and analysis respectively. Findings indicate that substantial part of Buhari's first tenure was spent on foreign trips which did not go down well with the populace given its implications on governance and Nigeria's struggling economy. On the basis of the above the article recommended amendment of Section 145 and 46 of the 1999 Constitution and National Health Act respectively to confer automatic acting capacity on Vice Presidents and Deputy Governors once a letter is transmitted to Legislature in respect to unavailability of the occupants of the offices and the breach of these laws made impeachable offenses.
\end{abstract}

Keywords: Foreign Trips, Crisis of Governance, Absence of Father Theory, Controversy, Medical Tourism

\section{INTRODUCTION}

The destinies of nations, no doubt, have become increasingly interdependent in the $21^{\text {st }}$ century more than they had been in the past centuries. Quite very often, many domestic issues, especially diverse security challenges tend to acquire gargantuan momentum and transmogrify to international imbroglio by crisscrossing the national boundaries and jurisdictional competencies of originating nation(s). Therefore, national leaders and international organisations have since recognised the commonality of humanity, that although our cultures, histories and governments may be different, however, in the face of insecurity and developmental challenges, our destinies are one and the same. Arising from this recognition, therefore, the mounting necessity of promoting collaboration and forging bilateral and multi-lateral collaborations for sustainable development and peaceful coexistence in an otherwise tension-soaked world has thus been acknowledged and pursued (Adamu, 2002). In their very pursuit and in keeping with other diplomatic exigencies of their offices, national leaders-Presidents, Prime Ministers, Heads of States and Governments, Queens, Kings, Emperors, Chancellors, etc-do frequently embark on foreign or international trips. Like diplomats, presidents take to international trips for the purposes of creating and maintaining strong international ties related to peacekeeping, war, trade, economics, culture, environmental issues, or human rights. During such trips, alliances are created and treaties signed, all of which are ideally geared at protecting their home country's citizens, repairing relationships between nations, and creating lasting bonds that help them shape foreign policy.

However recent events tend to suggest that Nigeria Leaders are abusing the privileges as the greater part of their tenure are spent on foreign trips with the attendant socio-economic and political consequences. Thus this developing trend has elicited concern among the populace as to their rethinking of the relevance or otherwise of such trips by their leaders. For instance ever since President Buhari's assumption of office in 2015, he has not concealed his penchant for foreign trips. Buhari's presidential trips so far can be categorized into two, viz: official work trip and medical trip. For simplicity and analytic categorization, the rest of all the other trips not manifestly associated with medicals have been grouped under the official trip category. In this connection, he has, between 2016 and August $3^{\text {rd }} 2018$, embarked on over thirty-seven (37) international trips and has visited about 22 
countries of the world. Between February $15^{\text {th }}, 2016$, the day President Muhammadu Buhari first embarked on a six day "Medical Vacation" to London and May $8^{\text {th }}, 2018$, when he took off to London for "Medical Review", President Buhari travelled to the United Kingdom on health/medical grounds on six (6) separate occasions. In 2017 alone, he spent a total of one hundred and fifty four (154) days in London on two separate medical visits. Between February $15^{\text {th }}, 2016$ and August $3^{\text {rd }} 2018$, President Buhari had embarked on over forty-three (43) international trips and has visited 23 countries of the world, very much to the dissatisfaction of concerned Nigerians. Even the media are awash with criticisms against his frequent trips, a repeated indulgence that has variously earned for him the names: "Nigeria's Junketer-In-Chief" and "Ambassador President" (Sahara Reporters, November 27, 2015; Buari, 2016).

The anger and indignation of Nigerians spring in part from the fact that in April 2016, Buhari had told the nation that he was not a fan of medical tourism, and that he would not encourage the political class to take to the skies for medical reasons either. $\mathrm{He}$ had assured Nigerians that "while this administration will not deny anyone of his or her fundamental human rights, we will certainly not encourage expending Nigerian hard-earned resources on any government official seeking medical care abroad, when such can be handled in Nigeria" (Egbas, 2018, p.2).

As an opposition candidate before the election that made him president, Buhari was one of the outstanding and vociferous critics of President Goodluck Jonathan's frequent trips. He had condemned, whole and entire, both Goodluck and Obasanjo's foreign trips. As the presidential candidate of the All Nigerian Peoples Party (ANPP) in 2003, Buhari/Okadigbo's campaign posters had read: "What we'll not do: Spending 110 days in a year globetrotting. We'll face domestic issues head-on. It's a promise"

It's ironic that years later, Buhari has earned for himself Nigeria's most traveled president within a year. The sudden turn around and hysterical enthusiasm with which President Buhari is warmly embracing the very "taboos" he had criticized, coupled with the glowing skeptical questions Nigerians have been asking about Buhari's sincerity to fighting corruption and fulfilling his lofty campaign promises have made Nigerians become apprehensive of his credibility, honesty, sincerity, public trust, accountability and transparency, all of which define good governance.

Apparently speaking the minds of many Nigerians, Obioha (2015) wonders how these constant foreign jamborees have been and/or would be able to address the litanies of problems and challenges confronting the country. He is convinced that no amount of shuttle diplomacy will resolve the brigandage and lawlessness of Fulani herdsmen that unleash their cattle on other people's farms and also kill their victims; that no amount of shuttle diplomacy will increase the quantity of electric power generated in the country, and that no amount of shuttle diplomacy will stop alleged secret recruitments in some Federal Government agencies and parastatals in recent times, including the Immigration, Customs and others. Having explored the length and breadth of President Buhari's international presidential trips and all that it stands for, Obioha $(2015$, p.1) resignedly remarked that:

No amount of foreign trips will stop the preponderance of ghost workers in the payroll of some of these agencies. Such travels will not put food on our tables, supply Nigerians fuel for their vehicles or defeat the Boko Haram insurgency or rescue the abducted Chibok school girls. Such jamborees, he added, cannot increase our foreign exchange earnings, which had dipped in recent times. The shuttle diplomacy will not fix our dilapidated road infrastructure, health or education sector. It will not prevent the pipeline vandals from doing what they know best or the Indigenous People of Biafra (IPOB) and other self-determination agitators from piling their occasional pressure on all of us.

Apart from the economic concerns and financial implications of Buhari's trips raised by Nigerians, his continued absence and the undisclosed circumstances surrounding his ailment also became very controversial. For clarity, controversy is a state of prolonged public dispute or debate, usually concerning a matter of conflicting opinion or point of view. By its very nature, therefore, controversies tend to generate disagreement and conflicts, which depending on how they are managed, may threaten the entire political system at large or plunge it into cataclysm.

Existing analyses on the subject matter tend to have focused mainly on Obasanjo's shuttle diplomacy. This is however understandable given the fact that the topic and the central issues, apart from being 
recent, have attracted less serious academic enquiries. However available literature suggested that frequent Presidential overseas trips do not enjoy popular acceptability as Onukwugha (2018), Onomuakpokpo (2016), Nwaeze (2016), Zeneli (2014), Adamu (2002) among others saw these trips as unwarranted waste of fund and scarce resources, even in the face of crippling demands for frugal expense of resources. These authors, however, were mute on whether President Buhari's frequent trips undermined governance, threatened regime stability and above constitute an infringement on Section 145 of the 1999 Constitution and Section 46 of the National Health Act. Moreover, while literature on the presidential medical tourism admitted that controversies seem to trail frequent medical trips by frontline public servants in Nigeria, especially the presidents, the works failed to systematically articulate the various controversies that trailed them and how they constituted a threat to Nigeria's socio-economic and political unity cum stability. Based on the foregoing this article became imperative as it examined the impact of the abuse of presidential international trips on the crisis of governance in Nigeria, with special focus on President Buhari's first tenure, 2015-2019 .

\section{Presidential Abuse of Foreign Trips and Crisis of Governance in Nigeria: A Theoretical Exposition}

The study relies on the Absence of Father Theory, which was propounded in 1982 by two anthropologists, Pat Draper and Henry Harpending. According to them, father absence is a term used by researchers to indicate that a child has lived for part or all of their childhood in a house without their biological father. This will be because the child's parents have split up or because they never lived together in the first place. It does not usually apply to children whose fathers have died, as this is a very different kind of psychological event. It also does not mean that the children had no contact with their father or that they did not have a good relationship with their father.

Mott (1993) later gave a general philosophical orientation of the Absence of Father as that which follows when we think of fatherless homes and what they may mean for children. According to the author, we are thinking essentially of the notion of change - the relief, trauma, or disruption associated with a father's leaving the home. Typically one thinks of families becoming poorer and perhaps, at least temporarily, of experiencing higher levels of stress. In this connection, Jay Belsky, along with Pat Draper again, and their colleague, Lawrence Steinberg in 1991 attempted to give a developmental model for how this phenomenon occurred. They suggested that family stress (including father absence) affected parenting practices (e.g. the more stressed the family, the harder it was for the parents to spend quality time with the children), which affected how the children's attitude to relationships developed and also their psychological coping practices, which in turn affected their physical development.

Although the theory has a psychological origin and dwells so much on family, its political and general social utility cannot be gainsaid. According to the organic theory of the state (whether patriarchal or matriarchal), the state is believed to have originated from the family in a network of kinship and consanguineous affinities. In this regards, the Nigeria state is seen as a patriarchal family headed by a father (President Muhamadu Buhari), whose frequent absence from Nigeria has the inherent capacity of affecting the children's (the citizens') psychological coping practices, and which in turn would affect their contribution to national development. Like Mott (1993) rightly argued, the "trauma or disruption associated with a father's leaving the home" soon came to light and found expression in anti-Buhari resume or resign protest/counter-protest in Abuja, the Nigeria Medical Association Protests, etc. It is to these and other manifestations of the "trauma" and disruptions occasioned by President Buhari's frequent and protracted absence that we now turn to in details.

\section{MeTHODOLOGY}

Documentary method was deployed in gathering data. It is important to note that documentary method of research data gathering is that approach that helps the researcher to glean information and data from an already documented source. Documentary method was considered most appropriate given that secondary data constitute bulk of the data used in the analysis. Therefore we essentially relied on secondary sources of written records like Nigerian Dailies, official publications of Federal Government of Nigeria, Non-governmental Organisations, and opposition political parties among others. The merits of secondary sources of data is that of economy and the fact that gathering of 
information does not require the co-operation of the individual (particularly Buhari) about whom information is being sought.

Content Analysis was adopted in the analysis of data generated. This method involves obtaining indepth information about the units of analysis of a given item of study. Being a method with high utility in qualitative research with the most significant feature of relying heavily on skills, creativity and abilities of the researcher, it involves processes of interpretation and creativity and analytic sagacity. Although content analysis has its origin in information science and mass communication, its utility in the social sciences, nay, Political Science, has acquired remarkable popularity because of its systematic revelations of evidential facts, among others. The article analyzed the contents of information collected based on the theoretical framework thereby drawing conclusions. This method is mainly associated with textual and contextual analysis of already existing information on the phenomenon being investigated. It involves the presentation, reading, analysis, critique and discussion of relevant information gathered from the different categories of sources, from which conclusion can be drawn. This particular feature of Content Analysis makes it go hand in glove with the documentary method of data gathering. In effect, Content Analysis as a scholarly procedural process entails the systematic making of sense from a mass of documented/documentary data.

\section{Interpretation of Section 145 of the 1999 Constitution and Anti-Buhari Resume or Resign Protest/Counter-Protest in Abuja}

On May 7 (Sunday) 2017, President Muhammadu Buhari left for London to attend to his ailing health. It should be noted however that this particular trip was not the first time the President was travelling to the UK on health grounds. In fact, since assuming office as Nigeria's democratically elected President on May 29, 2015, President Buhari had been away four times on similar vacations, while handing over power to his deputy, Yemi Osinbajo as acting President, in compliance with Section 145 (1) of the 1999 constitution. Okakwu (2017, para.1) chronicled it as follows:

During his first trip, eight months after assuming office, Mr. Buhari departed the country on February 5, 2016 to return five days later according to a letter signed by his special assistant on media, Femi Adesina. Exactly four months later on June, 5 2016, the president embarked on a second journey to London, this time to attend to a problem with his ear, his aides said. The subject of Mr. Buhari's health started dominating the national discuss, when during his third trip, on January 19, Mr. Buhari extended his medical vacation, after an initial announcement that his trip would last ten work days.

The said Section 145 of the 1999 Constitution (as amended) states: "Whenever the President is proceeding on vacation or is otherwise unable to discharge the functions of his office, he shall transmit a written declaration to the President of the Senate and the Speaker of the House of Representatives to that effect, and until he transmits to them a written declaration to the contrary, the Vice President SHALL perform the functions of the President as Acting President."

What this section is saying in essence is that anytime the President deems it expedient to transmit a written declaration or letter to the President of the Senate and Speaker of the House of Representatives, the Vice President automatically assumes the position of an Acting President and perform the functions of the President. However, the written declaration or letter transmitted to the President of the Senate and the Speaker of the House of Representatives by President Muhammadu Buhari conveying his decision to proceed on medical vacation ignited an avoidable controversy regarding the status and role of Prof. Yemi Osinbajo, SAN for the period that Mr. Buhari's medical vacation will subsist. It reads: "In compliance with section 145 (1) of the 1999 Constitution as amended, I wish to inform the Distinguished Senate that I will be away for a scheduled medical follow-up with my doctors in London. The length of my stay will be determined by the doctor's advice. While I am away, the Vice President will coordinate the activities of the government. Please accept, the Distinguished Senate President, the assurances of my highest consideration".

The controversial flavour of the letter/declaration of intent is inherent in its opportunistic avoidance of the constitutionally guaranteed automatic transformation of the Vice President to President. In particular, the part of the letter that elicited public debate is where Mr. Buhari offered his view on the 
role his Vice; Mr. Osinbajo will play in his absence. He stated thus: "While I am away, the Vice President will coordinate the activities of the government". While the role assigned by President Buhari to Vice President Osinbajo may look ostensibly awesome, it is technically and tactically reductionist. Like Effiong (2017) rightly noted, many commentators have interpreted this statement to mean that Osinbajo will not assume or exercise the functions of the office of the President as an Acting President, but will merely "coordinate the activities of the government" only as the Vice President of Nigeria. But the true position is that:

There is no office with the appellation "Coordinator of Nation's Affairs" under our Constitution. Buhari cannot amend the Supreme Law of the Land by implication. If Osinbajo is to coordinate the activities of the government while Buhari is away, he can only do so as the Acting President of Nigeria. Anything contrary is ultra vires, illegal, unconstitutional, null and void and of no effect whatsoever...Had the President proceeded on vacation to London without notifying the President of the Senate and Speaker of the House of Representatives, Prof. Osinbajo would have continued to "coordinate the activities of the government" as Vice President for the next 21 days, after which the National Assembly shall pass a resolution empowering him to perform the functions of the office of President in line with Section 145 (2) of the Constitution (Effiong, 2017, para. 16).

While President Buhari remained outside the country, the controversy surrounding his health and fitness to continue in office lingered. With the continuous extension of his medical leave without a specific date of return, Nigerians became apprehensive and began to express concerns. Therefore, about 90 days after his departure, a group of Nigerians led by popular entertainer, Charles Oputa, also called Charly boy, began a protest to demand Mr. Buhari's compulsory return or resignation with the hash tag \#ResumeOrResign. Five days after the protesters began their call for Mr. Buhari's compulsory return, a pro-Buhari group, led by Goodluck Obi, began a counter protest urging the president to rather focus on getting better before returning; a development which resulted in a clash between the two groups (Okakwu, 2017). He added that few days after, the \#ResumeOrResign group took their protest to the Wuse Market, the largest market in the Nigerian capital Abuja, and were attacked by suspected supporters of the president. The market was subsequently shut down due to the violence which took an ethnic dimension, the kind of which that could lead to inter ethnic war (Okakwu, 2017). Braving the pains of the violent attacks, the protesters who were demanding that the President should return immediately or resign, vowed to continue their protest despite the attacks. One of the leaders of the protest, Deji Adeyanju, according to (Okakwu, 2017, para. 4) vociferously stated that: "We reiterate commitment to remain resolute in demanding full disclosure regarding the state of health of the President. It is the right of the Nigerian people to know the true state of health of the man they voted into power and for whose healthcare they are paying".

Though that above incident was the height of presidential recklessness and abuse of office, the period as witnessed several other trips both on official and medical grounds and the attendant leadership crises as articulated in the table below.

Table1. List of Presidential Foreign Trips Made by Buhari, 2015-2019

\begin{tabular}{|l|l|l|l|}
\hline Country & Areas Visited & Date & Purpose \\
\hline Niger & Niamey & 3 June, 2015 & Anti-Boko Haram summit \\
\hline Chad & N'Djamena & 4 June, 2015 & State Visit \\
\hline Germany & Munich & 7-8 June, 2015 & 42nd G7 summit \\
\hline South Africa & Johannesburg & $12-13$ June, 2015 & 25th African Union Summit \\
\hline United States & $\begin{array}{l}\text { Washington, } \\
\text { D.C., }\end{array}$ & $19-23$ July, 2015 & State Visit \\
\hline Cameroon & Yaoundé & 29-30 July, 2015 & State Visit \\
\hline Benin & Cotonou & 2-3 Aug, 2015 & Independence Celebrations \\
\hline Ghana & Accra & 7 Sept. , 2015 & State Visit \\
\hline France & Paris & 14-16 Sept., 2015 & State Visit \\
\hline United States & New York City & 24-29 Sept. , 2015 & $\begin{array}{l}\text { 70th session of the United Nations } \\
\text { General Assembly }\end{array}$ \\
\hline India & New Delhi & 26-30 Oct. , 2015 & Third India Africa Forum Summit \\
\hline
\end{tabular}


Presidential Abuse of Foreign Trips and Crisis of Governance in Nigeria: A Reflection on Muhamadu Buhari's Regime, 2015-2019

\begin{tabular}{|c|c|c|c|}
\hline Sudan & Khartoum & 30 Oct. , 2015 & State Visit \\
\hline Iran & Tehran & $22-24$ Nov. , 2015 & 3rd Gas Exporting Countries Forum \\
\hline Malta & Valletta & $28-30$ Nov. , 2015 & $\begin{array}{l}2015 \text { Commonwealth Heads of } \\
\text { Government summit. }\end{array}$ \\
\hline France & Paris & 30 Nov. - 1 Dec. 2015 & Paris Conference of Parties \\
\hline South Africa & Johannesburg & $4-5$ Dec. , 2015 & China Africa summit \\
\hline Benin & Cotonou & 8 Jan., 2016 & $\begin{array}{l}\text { 11th summit of the Heads of State of the } \\
\text { Niger Basin Authority }\end{array}$ \\
\hline $\begin{array}{l}\text { United Arab } \\
\text { Emirates }\end{array}$ & Abu Dhabi & 17 - 20 Jan., 2016 & World Future Energy Summit \\
\hline Ethiopia & Addis Ababa & 26 Jan. , 2016 & $\begin{array}{l}\text { 26th Summit of African Union Heads of } \\
\text { State and Government }\end{array}$ \\
\hline Kenya & Eldoret, Nairobi & $27-29$ Jan. , 2016 & State Visit \\
\hline France & Strasbourg & $2-4$ Feb., 2016 & Official Visit \\
\hline $\begin{array}{l}\text { United } \\
\text { Kingdom }\end{array}$ & London & $5-10$ Feb., 2016 & Vacation \\
\hline Egypt & Sharm El Sheikh & 18 Feb. , 2016 & Sharm el-Sheikh 'Africa 2016' \\
\hline Saudi Arabia & $\begin{array}{l}\text { Riyadh, Jeddah, } \\
\text { Mecca, Medina }\end{array}$ & $22-27$ February, 2016 & State Visit \\
\hline Qatar & Doha & $27-28$ Feb., 2016 & OPEC Meeting \\
\hline $\begin{array}{l}\text { Equatorial } \\
\text { Guinea }\end{array}$ & Malabo & 14 March , 2016 & State Visit \\
\hline United States & Washington, D.C. & 30 March - 3 April , 2016 & 4th Nuclear Security Summit \\
\hline China & Beijing & $11-14$ April, 2016 & State Visit \\
\hline $\begin{array}{l}\text { United } \\
\text { Kingdom }\end{array}$ & London & 13 -15 May, 2016 & Anti-Corruption Summit \\
\hline $\begin{array}{l}\text { United } \\
\text { Kingdom }\end{array}$ & London & $6-19$ June, 2016 & Medical Visit \\
\hline Chad & N'Djamena & 8 Aug., 2016 & Inauguration of Idris Deby \\
\hline Kenya & Nairobi & $27-28$ Aug. , 2016 & Tokyo Conference on Africa \\
\hline United States & New York City & $11-15$ Sept., 2016 & $\begin{array}{l}\text { Seventy-first session of the United } \\
\text { Nations General Assembly }\end{array}$ \\
\hline Germany & Berlin & $13-16$ Oct., 2016 & State Visit \\
\hline Morocco & Marrakesh & $14-18$ Nov. , 2016 & $\begin{array}{lll}\begin{array}{l}\text { United Nations } \\
\text { conference }\end{array} & \text { Climate } & \text { Change } \\
\end{array}$ \\
\hline Senegal & Dakar & 5-7 Dec. , 2016 & $\begin{array}{l}\text { Third Dakar International Forum on Peace } \\
\text { and Security in Africa }\end{array}$ \\
\hline Gambia & Banjul & 13 Dec. , 2016 & ECOWAS summit \\
\hline Ghana & Accra & 7 Jan., 2017 & Inauguration of Nana Akufo-Addo \\
\hline Gambia & Banjul & 13 Jan., 2017 & ECOWAS mediation meeting \\
\hline Mali & Bamako & 13-14 Jan. , 2017 & 27th Africa France Summit \\
\hline UK & London & 19Jan. - 10 March, 2017 & Medical Vacation \\
\hline UK & London & 7 May, 2017 & Medical Check ups \\
\hline UK & London & 16-20 April, 2018 & $\begin{array}{l}\text { Attended the Commonwealth Heads of } \\
\text { Government Meeting }\end{array}$ \\
\hline US & Washington & 30 April, 2018 & Working Visit. \\
\hline UK & London & 3-13 Aug., 2018 & 10 working days vacation \\
\hline France & Paris & 10-13 Nov.,2018 & Paris Peace Forum \\
\hline
\end{tabular}

Source: Compiled by the researcher from https://en.wikipedia.org/wiki/List_of_international_presidential _trips_made_by_Muhammadu_Buhari

\section{Violation of Section 46 of the National Health Act and the Nigeria Medical Association Protests}

Hope always seems to have been lost when those who should protect are seen destroying the very values they have been charged to look after. And in no sane society is such act of commission taken lightly. Such was the case of the flouting of section 46 of the National Health Act by President Buhari. As the President of the country, Mr Buhari is unarguably the chief custodian of all public laws operating in Nigeria, including the National Health Act, section 46 of which states that: 
Without prejudice to the right of any Nigerian to seek medical check-up, investigations or treatment within and outside Nigeria, no public officer of the Government of the Federation or any part thereof shall be sponsored for medical check-up, investigations or treatment abroad at public expense except in exceptional cases on the recommendation and referral by the medical board and which recommendation or referral shall be dully approved by the Minister or the Commissioner as the case may be.

In truth, however, the above section of the law/act has since the ascendance of President Buhari been observed in its breaches. Worried by this ugly development, the NMA speaking through its President, Prof. Mike Ogirima on $2^{\text {nd }}$ November, 2016 threatened to file a lawsuit against the Federal Government as well as embark on a bi-weekly protest march to Aso Rock over the nonimplementation of the National Health Act 2014 (Ojo, 2016). While the NMA threat of strike lommed, the Resident Doctors under the umbrella of the National Association of Resident Doctors, NARD embarked on nationwide strike in 2017. Unbridled patronising of foreign hospitals to the neartotal neglect of Nigerian hospital as well as non-payment of accruals among other issues topped their list for embarking on the industrial action.

In fairness to the NMA, Buhari's medical trips, particularly that of June 2016 for a further evaluation of a niggling ear infection, came at a time when he had warned that the government would no longer bear the cost of the medical treatment of public officials abroad, especially for ailments that can be handled locally. Speaking at a Nigerian Medical Association function in Sokoto in April, the President, who was represented by the Minister of Health, Isaac Adewole, had said that the Nigerian government would "certainly not encourage expending Nigerian hard-earned resources on any government official seeking medical care abroad, when such can be handled in Nigeria" (Punch, 2016). It is however ironic that from the fuelling of the vehicles that often take him and his entourage from the villa to the Airport, through the procurement of the tickets, procurement of accommodations abroad for himself and his co-travellers and over bloated feedings, to the payment of budget-like medical/hospital bill and returning to Nigeria after many days of ridiculous extravagances, all come under the footing of public fund.

The Nigerian Medical Association having watched this in quietness over time therefore felt very constrained to state that this foreign medical trip flies in the face of the Federal Government's earlier declaration of her resolve to halt the embarrassing phenomenon of outward medical tourism, which as at the end of the year 2013 had led to a humongous capital flight of about \$1billion dollars, particularly from expenses incurred by political and public office holders (and their accompanying aides), whose foreign medical trips (most of which are unnecessary) were financed with tax payers' resources. The former president of the association, Dr. Osahon Enabulele, therefore charged Mr. President to:

make a clear public pronouncement on his resolve to show leadership by example with respect to the utilization of the medical expertise and facilities that abound in Nigeria by him and other members of the Federal Executive Council, particularly in concrete expression of section 46 of the National Health Act which seeks to address the abuse of tax payers' resources through frivolous foreign medical travels embarked upon by political and public office holders (Obinna, 2016, para.6).

He (Osahon) noted that it is on record that most public and political office holders who seek foreign medical care abroad are handled by Nigerian trained doctors in foreign lands particularly in the United Kingdom which has over 3000 Nigerian trained medical doctors, United States of America with over 5000 Nigerian trained medical doctors, amongst other foreign countries, most of whom left the shores of Nigeria on account of government's perennial failure to address the various push and pull factors which have consistently driven this yearly brain drain phenomenon in Nigeria (Vanguard, 2016). What is more, "Available records show that last year alone, 637 medical doctors emigrated due largely to poor working conditions and health facilities, insecurity, unpredictable and poor funding of Residency Training Programme, uncompetitive wages and job dissatisfaction" (Obinna, 2016, para.7).

Impacts of the Financial Costs of Frequent Presidential Foreign Trips on Struggling Nigerian Economy 
President Mohammadu Buhari's frequent trips have not augured well for the national economy. This has thus drawn increasing criticism from politicians and pundits who question the wisdom of the trips at a time when several domestic crises, including a crushing fuel scarcity, incessant attacks by Boko Haram terrorists, and blackouts demand urgent and focused attention. First, there is an unhealthy correlation between the volume of financial resources that goes into these trips and the financial shock absorbing/carrying capacity of the Nigerian economy. Sahara Reporters (2015, November 29) obtained information detailing the significant financial cost of trips undertaken by President Muhammadu Buhari and his entourage. The president's trips since assuming office at the end of May, 2015 have now stretched to 14. According to the report, an average two-day long presidential trip costs between $\$ 350 \mathrm{~K}$ and $\$ 500 \mathrm{~K}$. For instance, during Mr. Buhari's recent trip to Tehran, the capital of Iran, the estacode for accompanying Presidency officials was $\$ 105,000$. In addition, transportation costs stood at $\$ 45,000$, accommodation 200,000 , honorarium $\$ 10,000$, contingency 20,000 , with media coverage costing $\$ 10,000$.

The breakdown for the State visit/trip to Paris between 14 and 16 September, 2015 revealed that the estacode for accompanying Presidency officials was $\$ 130,000$ transportation was $\$ 55,000$ accommodation was $\$ 270,000$ honorarium was $\$ 10,000$ contingency was $\$ 20,000$ while media coverage $\$ 10,000$ making the total cost for the trip $\$ 495,000$.

Table2. Breakdown of the Expenditure of Buhari's Trip to Paris for Paris Conference of Parties between 30 November and 1 December, 2015

\begin{tabular}{|l|l|}
\hline Units of Expenditure & Cost \\
\hline Estacode for accompanying Presidency officials & $\$ 130,000$ \\
\hline Transportation & $\$ 55,000$ \\
\hline Accommodation & $\$ 270,000$ \\
\hline Honorarium & $\$ 10,000$ \\
\hline Contingency & $\$ 20,000$ \\
\hline Media coverage & $\$ 10,000$ \\
\hline Total cost & $\mathbf{\$ 4 9 5 , 0 0 0}$ \\
\hline
\end{tabular}

Source: Sahara Reporters (2015, Nov 29). President Buhari's foreign junkets add up to lots of cash. Retrieved from: http://saharareporters.com/2015/11/29/president-buhari\%E2\%80\% 99s-foreign-junkets-add-lots-cash.

Similarly, Sahara Reporters (2015, Nov 29) found that President Buhari's trip to South Africa which followed immediately from his visit to Paris, France had the following cost features and breakdown: Estacode for accompanying Presidency officials $=\$ 110,000$ transportation $=\$ 35,000$ accommodation $=\$ 220,000$ honorarium $=\$ 10,000$ contingency $=\$ 20,000$ and media coverage $=$ $\$ 10,000$ making a total of $\$ 405,000$.

Table3. Breakdown of Expenditure of Buhari's State Visit to South Africa for China Africa Summit between 4th and 5th December, 2015

\begin{tabular}{|l|l|}
\hline Units of Expenditure & Cost \\
\hline Estacode for accompanying Presidency officials & $\$ 110,000$ \\
\hline Transportation & $\$ 35,000$ \\
\hline Accommodation & $\$ 220,000$ \\
\hline Honorarium & $\$ 10,000$ \\
\hline Contingency & $\$ 20,000$ \\
\hline Media coverage & $\$ 10,000$ \\
\hline Total cost & $\mathbf{\$ 4 0 5 , 0 0 0}$ \\
\hline
\end{tabular}

Source: Sahara Reporters (2015, Nov 29). President Buhari's foreign junkets add up to lots of cash. Retrieved from: http://saharareporters.com/2015/11/29/president-buhari\%E2\% 80\%99s-foreign-junkets-add-lots-cash.

It should be noted that the information on Tables 1 and $\mathbf{2}$ are just those affecting the costs of only personnel from Aso Rock Villa, aides, protocol officers, members of the press, security personnel, a cook, a luggage officer and a steward. The Presidential Air Fleet (PAF) has a separate budget for fueling the planes as well as allowances for the presidential air fleet commander, pilots and the air stewards. The Office of the National Security Adviser funds those expenses. 
Similarly, the estacode did not reveal what President Buhari receives per night, as that expense is handled separately and secretly. In addition the Minister of Foreign Affairs and five members of his entourage who usually accompany President Buhari are not included in the costs as they get paid from the ministry's budget (Sahara Reporters, 2015, Nov 29).

Secondly, each of these trips has been embarked upon at a time when Nigeria's economy was operating at its relative historical lowest ebb. For this reasons have critics come down hard on President Buhari for engaging in international junkets at a time of rising disillusionment, with Nigeria mired in a crippling fuel scarcity, continuing violence by Boko Haram, and an economic downturn that has put pressures on banks and numerous businesses. Specifically on medical terms, many concerned Nigerians, including Human Rights experts, have cited the Freedom of Information Act as a basis, demanding the President to tell Nigerians how much it cost him to get the treatment he got in London, insisting that "If the money with which the President treated himself abroad did not come from his purse, then he is under obligation to disclose to Nigerians how much he spent from our money on his health care" (Vanguard, March 18). This is sequel to speculations that Buhari might have allegedly spent between $£ 200$ and $£ 250$ per hour for medical services in the UK. As noted by the former Minister of Finance, Mrs. Kemi Adeosun, Buhari and his entourage has pent N64billion on foreign trips in 2015 while only Buhari and Osinbajo spent N1.05bn on foreign trips in 2017 alone (Adetayo, 2017).

Most worrisome was the non-utilization the State House Clinic, despite enormous resources that are chandelled to annually. It should be noted that the Clinic, by the Act establishing it, is to provide healthcare for the President, Vice-President, their families and other employees of the presidency. What is more, on annual basis, huge budgetary allocation is approved for the upkeep and running of the Clinic. In 2016 budget alone, the State House Clinic reportedly received N787 million more in capital allocation than all the 16 teaching hospitals in the country combined. One would expect that by virtue of this huge allocation to the State House Clinic, President Buhari should be assured of state-ofthe-art medical care. This is however not the case as the President every now and again, within the period under study, sought medical care abroad, particular in London (the United Kingdom).

The net implication of these frequent junketing and their inauspicious timing has been a colossal underperformance of the economy, which culminated in painful recession between 2016 and 2017(Shaibu, 2018). There is a growing acceptance in Nigeria today that President Muhammadu Buhari has failed again in his headship of Nigeria. This time, as a supposed democratic leader, the failure is not just visible nationally but even the International Community, including two of the world's leading financial houses, the Hong-kong and Shanghai Banking Corporation, popularly called HSBC and the International Monetary Fund as well as the Economic Intelligence Unit of The Economist have recognized it and is not leaving any one in doubt about their observations (Shaibu, 2018). The particular aspect of the HSBC report that captured the attention of most Nigerians is where it noted as follow:

A second term for Mr. Buhari however raises the risk of limited economic progress and further fiscal deterioration, prolonging the stagnation of his first term, particularly if there is no move towards completing reform of the exchange rate system or fiscal adjustments that diversify government revenues away from oil...Buhari will once again lead the APC into the 2019 elections, although his approval ratings sit near alltime lows and this largely reflects the impact of Nigeria's painful recession in 201617 and the sustained economic hardship that has accompanied his presidency, including rapidly rising joblessness and poverty" (Shaibu, 2018, para. 2).

Sadly, the HSBC was to later face the Federal Government backlash/sanction for this damning report, including being labelled "a corrupt and biased institution, and instrument in the hands of the opposition, which had even allegedly been laundering money for corrupt Nigerian politicians" (Shaibu, 2018, para. 3). Also very pathetic is the fact that with the shrinking economy comes the rising of Nigeria's debt. The GDP reports of the National Bureau of Statistics since the first quarter of 2016 showed five consecutive quarters of negative GDP growth without concrete plans from the administration on how to exit the recession. According to the Debt Management Office, the Buhari administration met Nigeria's debts at N12.118tn at the end of June 2015, but today, the debt has risen 
to N21.725tn at the end of 2017, an addition of close to N10tn in three years (Onyekpere, 2018)! By June, Nigeria's total debt hit N22.37tn following the borrowing of N410bn by the Federal Government to fund the 2018 budget (Ndubuisi, 2018). This clearly shows that Nigeria's debt rises by N9.61tn under Buhari, having been incurred at a time the GDP is shrinking (Amaefule, 2018; Onyekpere, 2018).

In the light of the foregoing, particularly with reference to the overcharged political temperature and trepidation that the above controversial issues that pervaded the President's frequent and protracted medical trip in the United Kingdom injected into Nigeria's political system, we validate and accept the second hypothesis of the study, which states that: The controversy that trailed Buhari's medical trips to London threatened Nigeria's political and economic stability.

\section{CONCLUSION}

This article examined the impact of abuse of Presidential international trips on crisis of governance in Nigeria between 2015 to 2019. The study argued that president of Nigeria, General Mohammadu Buhari has demonstrated unrestrained penchant for travelling outside the country at will without giving heed to the existential socio-economic and political realities of the Nation. Even more worrisome is the huge financial expenses that have allegedly gone into these frequent and protracted trips. The continuous and contentious extension of his medical leave without a specific date of return, coupled with the rumors of his death in UK during this period compelled Nigerians to express deep worries and concerns. In specific terms, a group of Nigerians led by the popular entertainer, Charles Oputa, also called Charly boy, began a protest to demand Mr. Buhari's compulsory return or resignation with the hash tag \#ResumeOrResign. Arising logically therefore from the empirical verifications, the study found amongst other things that the fear, worries and agitations of Nigerians concerning President Buhari's frequent international trip, especially as it reflects on poor governance, economic extravagance/waste and over all insensitivity to the economic strictures and social undercurrents in Nigeria are not unfounded, but real! It is on the strength of this that the study concludes that the controversy that trailed Buhari's frequent foreign trips undermined governance and political stability through the attendant riotous ripples occasioned by his long and frequent absence. In the light of the above, the study recommends that the National and State House of Assemblies should confer automatic acting capacity for Vice Presidents and Deputy Governors once a letter is transmitted to them in respect to Section 145 of the 1999 Constitution (as amended) irrespective of the wording of the letter from Presidents or Governors and the break of the law made impeachable offense. Section 46 of the National Health Act should be amended with a view of highlighting specific conditions and categories of ailment upon which a political office holder should access public fund for oversea medical treatment and its violation should be made an impeachable offence.

\section{REFERENCES}

[1] Adamu, S. Nigeria: Understanding president Obasanjo's foreign trips. 2002, July 30. This Day. Retrieved from: https://allafrica.com/stories/200207300537.html 17/08/2018 on $26^{\text {th }}$ August, 2018.

[2] Sahara Reporters. Nigeria's junketer-in-chief president Muhammadu Buhari arriving to participate at the opening of the 2015 Commonwealth heads of government meeting in Malta. 2015, November 27. Sahara Reporters. Retrieved from: https://www.saharareporters.com.nigerias-junketer-in-chief-presidentmuhammad u-buhari-arriving-to-participate-at/10153151108882703/ on 02/10/2018

[3] Buari, J. How much does one trip of Buhari cost. 2016. Legit.ng. Retrieved from: https://www.legit. ng/651581-details-much-foreign-trips-president-buhari-cost.html 01/10/2018

[4] Egbas, J. Buhari: All the times president has flown to London for medical vacation. 2018, May 9. Pulse.ng. Retrieved from: https://www.pulse.ng/news/local/all-the-times-buhari-has-flown-to-london-formedical-vacation-id8357748.html 21/10/2018

[5] Obioha, R. Buhari's shuttle diplomacy and groaning citizenry. 2016, April 22. The Sun. Retrieved from: http://sunnewsonline.com/buharis-shuttle-diplomacy-and-groaning-citizenry/ on $26^{\text {th }}$ August, 2018.

[6] Onomuakpokpo, P. Nigeria: Buhari's foreign travels. 2016, February 11. The Guardian. Retrieved from: https://allafrica.com/stories/201602110500.html on 07/09/2018

[7] Nwaeze, A. Buhari's frequent trips is draining Nigeria's purse- says Gov. Fayose. 2016. Buzznigeria. Retrieved from http://buzznigeria.com/buharis-frequenttrips-is-draining-nigerias-purse-says-govfayose/ on 06/09/2018. 
[8] Mott, F. L. Absent fathers and child development: Emotional and cognitive effects at ages five to nine. 1993. Retrieved from: https://www.nlsinfo.org/sites/nlsinfo.org/files/attachments/121214/MottAbsentFathers and ChildDevelopment-1993.pdf on 14/04/2019

[9] Okakwu, E. 100 days without the president: Controversy trails Buhari's continued absence from Nigeria. 2017, August 16. Premium Times. Retrieved from: https://www.premiumtimesng.com/news/headlines/24 0370-100-days-without-president-controversy-trails-buharis-continued-absence-nigeria.html on 08/04/20 19

[10] Effiong, I. Osinbajo is the acting president of Nigeria. 2017, May 10. The Nation. Retrieved from: https://www.thecable.ng/osinbajo-acting-president-nigeria-simpliciter on 10/04/2019

[11] Ojo, J. The non-implementation of Nigeria's National Health Act. 2016, November 2. Punch. Retrieved from: https://punchng.com/non-implementation-nigerias-national-health-act/ on 30/03/2019

[12] Punch. Buhari's gratuitous medical trip. 2016, June 16. Punch. Retrieved from: https://punchng .com/buharis-gratuitous-medical-trip/ on 05/03/2019

[13] Obinna, C. Commonwealth doctors condemn Buhari's medical trip to London. 2016, June 6. Vanguard. Retrieved from: https://www.vanguardngr.com/2016/06/commonwealth-doctors-condemn-buharismedical-trip-to-london/ on 4/10/2018

[14] Adetayo, O. 2017: Buhari, Osinbajo to spend N1.05bn on foreign trips. 2016, December 23. Punch. Retrieved from: https://punchng.com/2017-buhari-osinbajo-spend-n1-05bn-foreign-trips/ on 08/11/2018

[15] Shaibu, P. Buhari, Atiku and the dwindling economy. 2018, October 14. Vanguard. Retrieved from: https://www.vanguardngr.com/2018/10/buhari-atiku-and-the-dwindling-economy/ on 01/04/2019

[16] Onyekpere, E. Buhari's economic scorecard at 3 (1). 2018, June 4. Punch. Retrieved from: https://punchng.com/buharis-economic-scorecard-at-3-1/) on 08/02/2019

[17] Ndubuisi, F. Nigeria's Total Debt Hits N22.37tn in June. 2018, August 15. This Day. https://www.thisdaylive.com/index.php/2018/08/15/nigerias-total-debt-hits-n22-37tn-in-june/ on 09/04/ 2019

[18] Amaefule, E. Nigeria's debt rises by N9.61tn under Buhari. 2018, March 15. Punch. Retrieved from:https://punchng.com/nigerias-debt-rises-by-n9-61tn-under-buhari/ on 08/02/2019

Citation: Okorie Albert, Ph.D, et.al. "Presidential Abuse of Foreign Trips and Crisis of Governance in Nigeria: A Reflection on Muhamadu Buhari's Regime, 2015-2019” International Journal of Political Science (IJPS), vol 6, no.3, 2020, pp. 10-20. doi: https://doi.org/10.20431/2454-9452.0603002.

Copyright: (C) 2020 Authors. This is an open-access article distributed under the terms of the Creative Commons Attribution License, which permits unrestricted use, distribution, and reproduction in any medium, provided the original author and source are credited. 